Review

\title{
Role of the UPS in Liddle syndrome
}

\section{Daniela Rotin}

Address: Program in Cell Biology, The Hospital for Sick Children, and Biochemistry Department, University of Toronto, Ontario, M5G 1X8, Canada

Email: Daniela Rotin - drotin@sickkids.ca

Published: 21 October 2008

BMC Biochemistry 2008, 9(SuppI I):S5 doi:10.1 I86/I47I-209I-9-SI-S5

This article is available from: http://www.biomedcentral.com/I47I-209I/9/SI/S5

(c) 2008 Rotin; licensee BioMed Central Ltd.

This is an open access article distributed under the terms of the Creative Commons Attribution License (http://creativecommons.org/licenses/by/2.0), which permits unrestricted use, distribution, and reproduction in any medium, provided the original work is properly cited.

\begin{abstract}
Hypertension is a serious medical problem affecting a large population worldwide. Liddle syndrome is a hereditary form of early onset hypertension caused by mutations in the epithelial $\mathrm{Na}^{+}$channel $(\mathrm{ENaC})$. The mutated region, called the PY (Pro-Pro-x-Tyr) motif, serves as a binding site for Nedd4-2, an E3 ubiquitin ligase from the HECT family. Nedd4-2 binds the ENaC PY motif via its WW domains, normally leading to $\mathrm{ENaC}$ ubiquitylation and endocytosis, reducing the number of active channels at the plasma membrane. In Liddle syndrome, this endocytosis is impaired due to the inability of the mutated PY motif in ENaC to properly bind Nedd4-2. This leads to accumulation of active channels at the cell surface and increased $\mathrm{Na}^{+}$(and fluid) absorption in the distal nephron, resulting in elevated blood volume and blood pressure. Small molecules/compounds that destabilize cell surface $\mathrm{ENaC}$, or enhance Nedd4-2 activity in the kidney, could potentially serve to alleviate hypertension.
\end{abstract}

Publication history: Republished from Current BioData's Targeted Proteins database (TPdb; http://www.targetedproteinsdb.com).

\section{Protein pathway involvement in disease Introduction}

Elevated arterial blood pressure, or hypertension, poses a serious public health problem, affecting approximately $25 \%$ of the adult population in the industrial world [1], and becoming, along with obesity, a serious health problem in the developing world as well. In recent years, the causes of several genetic disorders leading to hypertension or hypotension have been identified, and deleterious mutations have been mapped to components of the aldosterone pathway, as well as to key ion channels and transporters expressed along the nephron. Prominent examples include Bartter syndrome type I, II or III, Gitelman syndrome, pseudohypoaldosteronism I (PHAI) and Liddle syndrome [2]; the latter two are associated with mutations in the epithelial $\mathrm{Na}^{+}$channel $(\mathrm{ENaC})$ and are discussed in this review, with a particular focus on Liddle syndrome, a hereditary form of hypertension.

\section{The epithelial $\mathrm{Na}^{+}$channel}

The amiloride-sensitive $\mathrm{ENaC}$ is an ion channel expressed in $\mathrm{Na}^{+}$-transporting epithelia such as those present in the distal nephron, respiratory epithelium, distal colon and taste buds [3]. In the kidney, it is primarily expressed in the distal connecting tubules (CNTs) and cortical collecting tubules (CCTs) of the nephron $[4,5]$, where it provides the rate limiting step for $\mathrm{Na}^{+}$(and fluid) reabsorption into the blood stream $[3,6,7]$. This regulation of $\mathrm{Na}^{+}$and fluid absorption is tightly controlled by the hormones aldosterone (i.e. the renin-angiotensin-aldosterone pathway) and vasopressin (antidiuretic hormone, ADH), which stimulate channel activity $[6,8]$. The single channel characteristics of $\mathrm{ENaC}$ reveal high selectivity for $\mathrm{Na}^{+}$over $\mathrm{K}^{+}$, low 
single channel conductance ( $\sim 5 \mathrm{pS})$, high sensitivity to amiloride ( 100 $\mathrm{nM}$ ) and slow gating [6]. ENaC activity is primarily regulated by control of its opening (Po) and numbers at the plasma membrane [8].

ENaC is comprised of three subunits, $\alpha, \beta$ and $\gamma$ [9], each consisting of two transmembrane domains flanked by a large extracellular loop and two intracellular N- and C-termini, and is preferentially assembled at a stoichiometry of $\alpha_{2} \beta \gamma[10,11]$ (although other configurations have been proposed $[12,13])$. Maximal channel activity is obtained when all three subunits are expressed together, but expression of $\alpha$ alone, or a combination of $\alpha \beta$, or $\alpha \gamma$, results in low or moderate channel activity, respectively [9].

Genetic disease-causing mutations in $\mathrm{ENaC}$, as well as mouse models, have shed important light on $\mathrm{ENaC}$ function and the pathology of ENaC-related diseases. For example, loss of function mutations in either $\alpha, \beta$, or $\gamma$ ENaC cause PHAI $[14,15]$, a salt-wasting disease leading to hypotension, which is also mimicked in knockout mouse models lacking $\beta$ or $\gamma \mathrm{ENaC}[16,17]$, or models expressing reduced levels of $\alpha \mathrm{ENaC}$ [18], all of which exhibit reduced levels of channel expression and activity $[9,19]$. In contrast to the ENaC loss of function mutations causing PHAI, gain of function mutations in this channel cause Liddle syndrome.

\section{Liddle syndrome}

Liddle syndrome (pseudoaldosteronism, OMIM 177200) is an autosomal dominant disease leading to early onset of hypertension. It is associated with hypokalemic alkalosis, reduced plasma rennin activity and low plasma aldosterone levels [20]. Over the past 12 years, work from Lifton's group (Yale University) and others has identified several deletions/mutations that cause Liddle syndrome, all of which map to $\beta$ or $\gamma \mathrm{ENaC}$ and lead to elevated channel numbers and activity at the plasma membrane, as assessed by heterologously expressing these mutant ENaCs in Xenopus oocytes or cultured mammalian cells $[2,21,22]$. These genetic defects either delete the C-terminus of $\beta$ or $\gamma \mathrm{ENaC}[23,24]$, or mutate a proline or a tyrosine within a short sequence, called the PY (Pro-Pro-X-Tyr) motif [25-28]. The PY motif, or extended PY motif (PPxYxxL $[21,29])$, is highly conserved in the C-termini of all ENaC subunits [26], and serves as a binding site for the Nedd4 family of ubiquitin ligases [30], as assessed by in vitro binding, yeast two-hybrid and co-immunoprecipitation assays, as well as by structural analysis (e.g. $[29,30])$.

\section{Regulation of ENaC by the ubiquitin system and its impairment in Liddle syndrome}

Ubiquitylation, carried out by the sequential activity of E1, E2 and E3 (ubiquitin ligase) enzymes, usually regulates stability of target proteins that are tagged with ubiq- uitin by the E3 ligases [31]. Most of these proteins are degraded by the proteasome [32]. Recent studies have demonstrated, however, that ubiquitylation of transmembrane proteins can tag them for endocytosis and/or vesicular sorting, often resulting in their degradation in the lysosome $[33,34]$. This is usually achieved by the presence of ubiquitin binding motifs or domains (e.g. UIM, UBA, CUE, GAT, UEV, VHS) within proteins such as epsin/ Eps15, Hrs and GGA, which function to recognize the ubiquitylated transmembrane proteins and facilitate their endocytosis or sorting [35].

Nedd4 family members are E3 ubiquitin ligases that comprise a $\mathrm{C} 2$ domain responsible for membrane targeting [36,37], three to four WW domains that bind the PY motifs of ENaC [29,30,38-42], and a ubiquitin ligase HECT (homologous to E6AP carboxyl-terminus) domain $[43,44]$ (Figures 1 and 2). Of the two closely related Nedd4 members, Nedd4-1 and Nedd4-2, the latter binds $\mathrm{ENaC}$ more strongly due to the presence of an additional, high affinity WW domain (WW3, out of four WW domains) $[41,42]$. Accordingly, Nedd4-2 was shown to effectively suppress $\mathrm{ENaC}$ activity by enhancing removal of the channel from the plasma membrane [45-47], and ubiquitylation of $\mathrm{ENaC}$ was demonstrated to destabilize cell surface ENaC [48] (Figure 2). Indeed, our recent work has demonstrated that Nedd4-2 can ubiquitylate ENaC present at the apical membrane of cultured kidney epithelial cells [49]. The few Nedd4-1 proteins that also contain this high affinity WW3 domain (e.g. human and Drosophila Nedd4-1) are also able to suppress ENaC activity when heterologously expressed in Xenopus oocytes or cultured cells, although in some cases this is prevented in the presence of the C2 domain (for example, in the case of human Nedd4-1 [41,47,50]), possibly (albeit speculatively) due to inhibitory interactions between the $\mathrm{C} 2$ and HECT domains.

Experiments performed in Xenopus oocytes or mammalian cultured cells that ectopically express ENaC reveal that unlike the ability of Nedd4-2 to induce removal of wildtype ENaC from the plasma membrane by ubiquitylation (likely linked to subsequent clathrin-mediated endocytosis [51]), Liddle syndrome mutations in the PY motif of $\beta$ or $\gamma \mathrm{ENaC}$ severely attenuate this removal, leading to increased retention of mutant $\mathrm{ENaC}$ at the cell surface and to elevated channel activity $[45,46,49]$ (Figure 2). Accordingly, conditional knockout mice bearing a deletion of the PY motif in $\beta E N a C$ (a mouse model for Liddle syndrome) develop hypertension that is induced by high salt diet [52]. Moreover, channel feedback inhibition by elevated intracellular $\mathrm{Na}^{+}$concentrations exhibited by wild-type $\mathrm{ENaC}$ (demonstrated ex vivo in the CCTs of rats [53]) is defective in $\mathrm{ENaC}$ bearing the Liddle syndrome mutations in the PY motif (as shown by ectopic expression of PY 

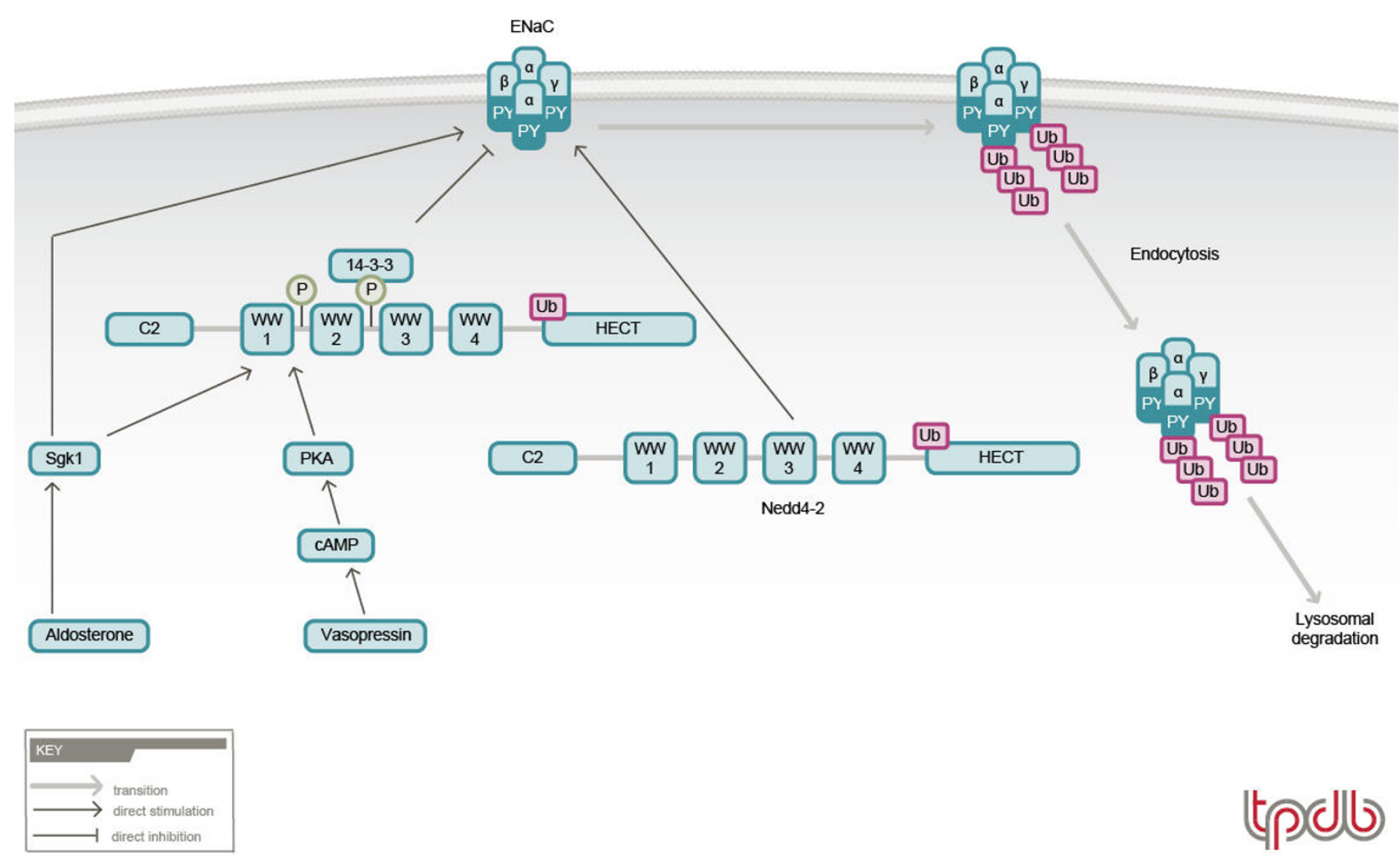

\section{Figure I}

Regulation of ENaC by Nedd4-2 in homeostasis. The ubiquitin ligase Nedd4-2 binds (via its WW domains) to the PY motifs of $\mathrm{ENaC}$, in turn ubiquitylating and targeting $\mathrm{ENaC}$ for endocytosis and lysosomal degradation. This process can be inhibited by Sgk l - or Akt-mediated phosphorylation of Nedd4-2, which leads to binding of I4-3-3 proteins to phosphorylated Nedd4-2, thus preventing Nedd4-2 from associating with ENaC and thus increasing ENaC levels at the plasma membrane. Sgk I can also upregulate $\mathrm{ENaC}$ independently of Nedd4-2.

motif-mutated ENaC in Xenopus oocytes [54]), further exacerbating $\mathrm{Na}^{+}$loading. Together, this results in increased $\mathrm{Na}^{+}$and fluid reabsorption in the distal nephron, and increased blood volume and blood pressure, which are hallmarks of Liddle syndrome.

As indicated in the section The epithelial $\mathrm{Na}^{+}$channel, $\mathrm{ENaC}$ is tightly (positively) regulated in the kidney by the mineralocorticoid hormone aldosterone. One of the recently discovered aldosterone targets is Sgk1, a Ser/Thr kinase from the Akt (PKB) family that was found to elevate $\mathrm{ENaC}$ levels/activity in response to aldosterone in rat or mouse kidney and in A6 cells (a Xenopus cell line endogenously expressing $\mathrm{ENaC}$ and responsive to aldosterone) [55,56]. This effect can be mediated either without (see below) or via regulation of Nedd4-2 (Figure 1). Nedd4-2 (but not Nedd4-1) possesses Sgk1 phosphorylation sites and, when phosphorylated by Sgk1 (in cultured cells), is prevented from downregulating $\mathrm{ENaC}$, leading to increased $\mathrm{ENaC}$ retention at the cell surface and thus increased
ENaC activity $[57,58]$. This effect is believed to be mediated by association of the adaptor protein 14-3-3, known to bind phosphoSer/Thr [59], with Ser-phosphorylated Nedd4-2, thus preventing Nedd4-2 from binding ENaC $[60,61]$ (by as yet unknown mechanism(s)). In support, the expression of 14-3-3 $\beta$ and Nedd4-2, as well as Nedd42 phosphorylation, were recently shown to be induced in CCT cells by dietary salt and by aldosterone [62-64]. However, aldosterone and Sgk1 can stimulate ENaC independently of Nedd4-2 and their role in Liddle syndrome is controversial: aldosterone and Sgk1 were found to increase cell surface abundance of $\mathrm{ENaC}$ channels bearing Liddle syndrome deletions/mutations (which cannot bind Nedd4-2) [65-68] and, importantly, CCTs harvested from mutant mice bearing a Liddle syndrome deletion [52] revealed a normal response to aldosterone [69].

In addition to aldosterone, the hormone vasopressin also increases $\mathrm{ENaC}$ activity (as well as water absorption) in the distal nephron by binding to $V_{2}$ receptors and stimu- 

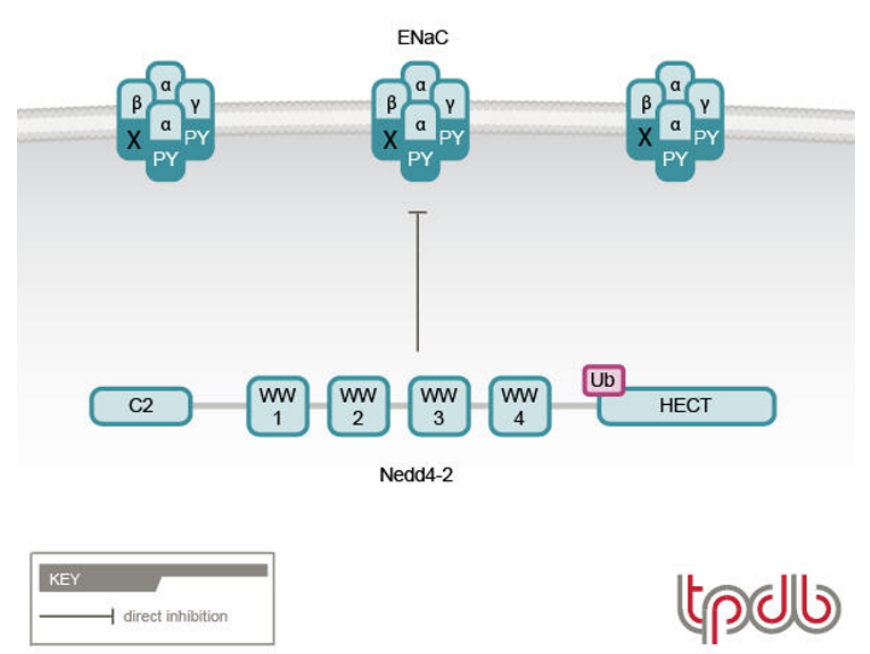

\section{Figure 2}

Regulation of ENaC by Nedd4-2 and its impairment in Liddle syndrome. In Liddle syndrome, deletion/mutation of the PY motif in $\beta \mathrm{ENaC}$ (or $\gamma \mathrm{ENaC}$, not shown) impairs the ability of Nedd4-2 to bind (and thus ubiquitylate) $\mathrm{ENaC}$, leading to accumulation of $\mathrm{ENaC}$ channels at the plasma membrane and increased channel activity. (Modified with permission from Staub and Rotin).

lating activation of adenylate cyclase and the release of cAMP [6]. cAMP increases the density of ENaC channels (endogenously or ectopically expressed in epithelial cells) at the plasma membrane $[70,71]$, an effect suggested to be impaired in channels bearing the Liddle syndrome PY motif mutations due to defective trafficking to the cell surface [72], or mobilization from a sub-apical pool [49]. Recent studies also suggested that Nedd4-2 phosphorylation by PKA (which is activated by cAMP) provides inhibitory function much like Sgk1, thus inhibiting the ability of Nedd4-2 to suppress ENaC, leading to increased cell surface abundance of this channel [73].

Among the other factors that regulate $\mathrm{ENaC}$ (aside from hormones, ions and Nedd4-2), are proteases such as CAP proteins and TMPRSS3, which activate ENaC by proteolytic cleavage of its ectodomains [3,74-77]. A recent paper suggests that Liddle syndrome mutations increase the number of cleaved (active) ENaCs at the cell surface (thus further increasing $\mathrm{Na}^{+}$absorption), and that Nedd4-2 and $\mathrm{ENaC}$ ubiquitylation regulate the number of cleaved channels at the plasma membrane [78].

\section{Disease models, knockouts and assays}

To date, only one mouse model for Liddle syndrome has been generated. These mice, created by the Rossier/ Hummler groups (Institut de Pharmacologie et de Toxicologie, Switzerland) in 1999, bear a deletion of the PY motif in $\beta \mathrm{ENaC}$ (a stop codon is inserted at a residue cor- responding to residue $\operatorname{Arg} 566$ in human $\beta \mathrm{ENaC}$, as found in the original pedigree described by R. Lifton [23]). The mice have no phenotype under a normal salt diet, but develop hypertension when fed a high salt diet [52]. To date, no other relevant knockout mice of Liddle syndrome have been developed.

\section{Disease targets and ligands}

Liddle syndrome patients are treated with the $\mathrm{ENaC}$ antagonist amiloride-triamterene and a low salt diet to stabilize their high blood pressure. While Liddle syndrome is a rare disorder, as are several genetic forms of hypertension [2], other forms of hypertension are very common in the population and have no known genetic components. Inhibiting $\mathrm{ENaC}$ activity, the rate limiting step in the regulation of $\mathrm{Na}^{+}$and fluid reabsorption in the nephron, could provide an attractive target to treat hypertension. With the advent of high throughput technology it is possible to test for inhibition of ENaC activity by screening with small molecules/compound libraries, with the hope of identifying inhibitory compounds that may be superior to amiloride and its analogs. In that regard, we have recently developed a high throughput assay that allows quantification of the amounts of cell surface ENaC (Chen and Rotin, unpublished). Given the key role played by the ubiquitin system/Nedd4-2 in regulating ENaC cell surface stability and $\mathrm{ENaC}$ function, identifying compounds that destabilize/decrease $\mathrm{ENaC}$ levels at the plasma membrane could have potential therapeutic benefits for the treatment of hypertension. Stimulating Nedd4-2 activity, which leads to ENaC endocytosis/degradation, could also be a possibility. However, since Nedd42 likely has other targets in other tissues/cells, this approach needs to be scrutinized to ensure it is targeted specifically to $\mathrm{ENaC}$ in the kidney. It is likely that use of putative compounds that aim to enhance ENaC internalization or Nedd4-2 activity would be more effective towards other forms of hypertension and not Liddle syndrome, since the latter carries mutations that already inhibit $\mathrm{ENaC}$ internalization and are insensitive to Nedd4-2.

\section{New frontiers in drug discovery}

Despite significant recent advances, several key questions remain to be answered regarding the regulation of $\mathrm{ENaC}$ by Nedd $4-2$ and the ubiquitin system. These include:

(i) How is sensing of elevation of intracellular concentrations of $\mathrm{Na}^{+}$(that normally shuts down $\mathrm{ENaC}$ ) related to the Liddle syndrome mutations? If this is regulated via Nedd4-2, how is Nedd4-2 (directly or indirectly) able to sense $\mathrm{Na}^{+}$?

(ii) How does phosphorylation of Nedd4-2 by Sgk1 (on sites not within the WW domains), which leads to binding 
of 14-3-3 to Nedd4-2, inhibit the association of Nedd4-2 with $\mathrm{ENaC}$, which is mediated via the WW domains?

(iii) What is the exact stoichiometry of Nedd4-2-ENaC interactions, and how is it that loss of only one PY motif is sufficient to cause Liddle syndrome?

(iv) How is the activity of Nedd4-2 itself regulated in the cell?

(v) What is the physiological function of Nedd4 proteins in vivo in mammals, especially in the kidney? The latter should be answered with the generation of knockout murine models for these proteins (not yet published). Future work will undoubtedly address these and other important questions that investigate the relationship between $\mathrm{ENaC}$ and the ubiquitin system.

\section{List of abbreviations used}

CCT: cortical collecting tubule; CNT: distal connecting tubule; ENaC: epithelial $\mathrm{Na}^{+}$channel; HECT: homologous to E6AP carboxyl-terminus; PHAI: pseudohypoaldosteronism I; PY: Pro-Pro-X-Tyr.

\section{Competing interests}

The author declares that they have no competing interests.

\section{Acknowledgements}

Work from the author's lab described in this review was supported by grants from the Canadian Institute of Health Research and the Canadian CF Foundation.

This article has been published as part of BMC Biochemistry Volume 9 Supplement I, 2008: Ubiquitin-Proteasome System in Disease Part 2. The full contents of the supplement are available online at http://www.biomedcen tral.com/l47|-209|/9?issue=SI.

Additional TPdb reviews on the ubiquitin-proteasome system are also available in BMC Biochemistry - see Volume 8 Suppl I http://www.biomedcen tral.com/l47|-209|/8? issue=SI.

\section{References}

I. Burt VL, Whelton P, Roccella EJ, Brown C, Cutler JA, Higgins M, Horan MJ, Labarthe D: Prevalence of hypertension in the US adult population. Results from the Third National Health and Nutrition Examination Survey, 1988-1991. Hypertension 1995, 25(3):305-313.

2. Lifton RP, Gharavi AG, Geller DS: Molecular mechanisms of human hypertension. Cell 200I, 104(4):545-556.

3. Rossier BC: The epithelial sodium channel: activation by membrane-bound serine proteases. Proc Am Thorac Soc 2004, I(I):4-9.

4. Duc C, Farman N, Canessa CM, Bonvalet JP, Rossier BC: Cell-specific expression of epithelial sodium channel alpha, beta, and gamma subunits in aldosterone-responsive epithelia from the rat: localization by in situ hybridization and immunocytochemistry. J Cell Biol 1994, I 27(6 Pt 2): 1907-1921.

5. Frindt G, Palmer LG: $\mathbf{N a}$ channels in the rat connecting tubule. Am J Physiol Renal Physiol 2004, 286(4):F669-674.

6. Garty H, Palmer LG: Epithelial sodium channels: function, structure, and regulation. Physiol Rev 1997, 77(2):359-396.
7. Kellenberger S, Schild L: Epithelial sodium channel/degenerin family of ion channels: a variety of functions for a shared structure. Physiol Rev 2002, 82(3):735-767.

8. Schild L: The epithelial sodium channel: from molecule to disease. Rev Physiol Biochem Pharmacol 2004, I 5 I:93-107.

9. Canessa CM, Schild L, Buell G, Thorens B, Gautschi I, Horisberger ID, Rossier BC: Amiloride-sensitive epithelial $\mathrm{Na}+$ channel is made of three homologous subunits. Nature 1994, 367(6462):463-467.

10. Firsov D, Gautschi I, Merillat AM, Rossier BC, Schild L: The heterotetrameric architecture of the epithelial sodium channel (ENaC). Embo J 1998, I7(2):344-352.

II. Kosari F, Sheng S, Li J, Mak DO, Foskett JK, Kleyman TR: Subunit stoichiometry of the epithelial sodium channel. J Biol Chem 1998, 273(22): I 3469-| 3474.

12. Snyder PM, Cheng C, Prince LS, Rogers JC, Welsh MJ: Electrophysiological and biochemical evidence that DEG/ENaC cation channels are composed of nine subunits. I Biol Chem 1998, 273(2):681-684.

13. Staruschenko A, Medina JL, Patel P, Shapiro MS, Booth RE, Stockand JD: Fluorescence resonance energy transfer analysis of subunit stoichiometry of the epithelial $\mathrm{Na}+$ channel. J Biol Chem 2004, 279(26):27729-27734.

14. Strautnieks SS, Thompson RJ, Gardiner RM, Chung E: A novel splice-site mutation in the gamma subunit of the epithelial sodium channel gene in three pseudohypoaldosteronism type I families. Nat Genet 1996, I3(2):248-250.

15. Chang SS, Grunder S, Hanukoglu A, Rosler A, Mathew PM, Hanukoglu I, Schild L, Lu Y, Shimkets RA, Nelson-Williams C, et al.: Mutations in subunits of the epithelial sodium channel cause salt wasting with hyperkalaemic acidosis, pseudohypoaldosteronism type I. Nat Genet I996, I 2(3):248-253.

16. Barker PM, Nguyen MS, Gatzy JT, Grubb B, Norman H, Hummler E, Rossier B, Boucher RC, Koller B: Role of gammaENaC subunit in lung liquid clearance and electrolyte balance in newborn mice. Insights into perinatal adaptation and pseudohypoaldosteronism. J Clin Invest 1998, 102(8):1634-1640.

17. McDonald FJ, Yang B, Hrstka RF, Drummond HA, Tarr DE, McCray PB, Stokes JB, Welsh MJ, Williamson RA: Disruption of the beta subunit of the epithelial $\mathrm{Na}+$ channel in mice: hyperkalemia and neonatal death associated with a pseudohypoaldosteronism phenotype. Proc Natl Acad Sci USA 1999, 96(4): $1727-|73|$.

18. Hummler E, Barker P, Talbot C, Wang Q, Verdumo C, Grubb B, Gatzy J, Burnier M, Horisberger JD, Beermann F, et al:: A mouse model for the renal salt-wasting syndrome pseudohypoaldosteronism. Proc Natl Acad Sci USA 1997 94(2I): $11710-11715$

19. Grunder S, Firsov D, Chang SS, Jaeger NF, Gautschi I, Schild L, Lifton RP, Rossier BC: A mutation causing pseudohypoaldosteronism type $I$ identifies a conserved glycine that is involved in the gating of the epithelial sodium channel. Embo J 1997, 16(5):899-907.

20. Liddle GW, Bledsoe T, Coppage WS Jr: Hypertension reviews. J Tenn Med Assoc 1974, 67(8):669.

21. Snyder PM, Price MP, McDonald FJ, Adams CM, Volk KA, Zeiher BG Stokes JB, Welsh MJ: Mechanism by which Liddle's syndrome mutations increase activity of a human epithelial $\mathrm{Na}+$ channel. Cell 1995, 83(6):969-978.

22. Firsov D, Schild L, Gautschi I, Merillat AM, Schneeberger E, Rossier $B C$ : Cell surface expression of the epithelial $\mathrm{Na}$ channel and a mutant causing Liddle syndrome: a quantitative approach. Proc Natl Acad Sci USA 1996, 93(26): 15370-15375.

23. Shimkets RA, Warnock DG, Bositis CM, Nelson-Williams $C$, Hansson JH, Schambelan M, Gill JR Jr, Ulick S, Milora RV, Findling JW, et al:: Liddle's syndrome: heritable human hypertension caused by mutations in the beta subunit of the epithelial sodium channel. Cell I994, 79(3):407-4I4.

24. Hansson JH, Nelson-Williams C, Suzuki H, Schild L, Shimkets R, Lu Y, Canessa C, Iwasaki T, Rossier B, Lifton RP: Hypertension caused by a truncated epithelial sodium channel gamma subunit: genetic heterogeneity of Liddle syndrome. Nat Genet 1995 , il (I):76-82.

25. Hansson JH, Schild L, Lu Y, Wilson TA, Gautschi I, Shimkets R, Nelson-Williams C, Rossier BC, Lifton RP: A de novo missense mutation of the beta subunit of the epithelial sodium channel 
causes hypertension and Liddle syndrome, identifying a proline-rich segment critical for regulation of channel activity. Proc Natl Acad Sci USA 1995, 92(25): I I 495-I I 499.

26. Schild L, Lu Y, Gautschi I, Schneeberger E, Lifton RP, Rossier BC: Identification of a PY motif in the epithelial $\mathrm{Na}$ channel subunits as a target sequence for mutations causing channel activation found in Liddle syndrome. Embo J 1996 I 5(10):238I-2387.

27. Tamura H, Schild L, Enomoto N, Matsui N, Marumo F, Rossier BC: Liddle disease caused by a missense mutation of beta subunit of the epithelial sodium channel gene. J Clin Invest 1996, 97(7): 1780- 1784

28. Inoue J, Iwaoka T, Tokunaga H, Takamune K, Naomi S, Araki M, Takahama K, Yamaguchi K, Tomita K: A family with Liddle's syndrome caused by a new missense mutation in the beta subunit of the epithelial sodium channel. J Clin Endocrinol Metab 1998, 83(6):2210-2213

29. Kanelis V, Rotin D, Forman-Kay JD: Solution structure of a Nedd4 WW domain - ENaC peptide complex. Nature Structure Biol 200I, 8(5):407-4I 2 .

30. Staub O, Dho S, Henry P, Correa J, Ishikawa T, McGlade J, Rotin D: WW domains of Nedd4 bind to the proline-rich PY motifs in the epithelial $\mathrm{Na}+$ channel deleted in Liddle's syndrome. Embo J 1996, I 5( I 0):237I-2380.

31. Hershko A, Ciechanover A: The ubiquitin system. Annu Rev Biochem 1998, 67:425-479.

32. Glickman $\mathrm{MH}, \mathrm{Ciechanover} \mathrm{A:} \mathrm{The} \mathrm{ubiquitin-proteasome} \mathrm{prote-}$ olytic pathway: destruction for the sake of construction. Physiol $\operatorname{Rev} 2002$, 82(2):373-428.

33. Hicke L: A new ticket for entry into budding vesicles-ubiquitin. Cell 200I, 106(5):527-530.

34. Staub O, Rotin D: Role of ubiquitylation in cellular membrane transport. Physiol Rev 2006, 86(2):669-707.

35. Hicke L, Schubert HL, Hill CP: Ubiquitin-binding domains. Nat Rev Mol Cell Biol 2005, 6(8):610-62I

36. Plant PJ, Lafont F, Lecat S, Verkade P, Simons K, Rotin D: Apical membrane targeting of Nedd 4 is mediated by an association of its C2 domain with annexin XIllb. J Cell Biol 2000, I 49(7): : 473- I 484.

37. Plant PJ, Yeger H, Staub O, Howard P, Rotin D: The C2 domain of the ubiquitin protein ligase Nedd4 mediates $\mathrm{Ca}$ +-dependent plasma membrane localization. I Biol Chem 1997 , 272(5 I):32329-32336.

38. Goulet CC, Volk KA, Adams CM, Prince LS, Stokes JB, Snyder PM: Inhibition of the epithelial $\mathrm{Na}+$ channel by interaction of Nedd4 with a PY motif deleted in Liddle's syndrome. J Biol Chem 1998, 273(45):30012-30017.

39. Harvey KF, Dinudom A, Komwatana P, Jolliffe CN, Day ML, Parasivam G, Cook DI, Kumar S: All three WW domains of murine Nedd4 are involved in the regulation of epithelial sodium channels by intracellular Na+. J Biol Chem 1999, 274( I 8): I 2525-I 2530.

40. Farr TJ, Coddington-Lawson SJ, Snyder PM, McDonald FJ: Human Nedd4 interacts with the human epithelial $\mathrm{Na}+$ channel: WW3 but not WWI binds to Na+-channel subunits. Biochem J 2000, 345(Pt 3):503-509.

4I. Henry PC, Kanelis V, O'Brien MC, Kim B, Gautschi I, Forman-Kay J, Schild L, Rotin D: Affinity and specificity of interactions between $\mathrm{Nedd} 4$ isoforms and the epithelial $\mathrm{Na}+$ channel. Biol Chem 2003, 278(22):20019-20028.

42. Kanelis V, Bruce MC, Skrynnikov NR, Rotin D, Forman-Kay JD: Structural determinants for high-affinity binding in a Nedd 4 WW3* domain-Comm PY motif complex. Structure 2006, I 4(3):543-553.

43. Rotin D, Staub $O$, Haguenauer-Tsapis R: Ubiquitination and endocytosis of plasma membrane proteins: role of Nedd4/Rsp $5 \mathrm{p}$ family of ubiquitin-protein ligases. J Membr Biol 2000, 176(I): $1-17$

44. Ingham RJ, Gish G, Pawson T: The Nedd4 family of E3 ubiquitin ligases: functional diversity within a common modular architecture. Oncogene 2004, 23(II): 1972-1984.

45. Abriel H, Loffing J, Rebhun JF, Pratt JH, Schild L, Horisberger JD, Rotin $D$, Staub O: Defective regulation of the epithelial $\mathrm{Na}+$ channe by Nedd4 in Liddle's syndrome. I Clin Invest 1999 , I 03(5):667-673
46. Kamynina E, Debonneville C, Bens M, Vandewalle A, Staub O: A novel mouse Nedd4 protein suppresses the activity of the epithelial Na+ channel. Faseb J 200I, I5(I):204-2I4.

47. Snyder PM, Olson DR, McDonald FJ, Bucher DB: Multiple WW domains, but not the $C 2$ domain, are required for inhibition of the epithelial $\mathrm{Na}+$ channel by human Nedd4. J Biol Chem 200I, 276(30):2832I-28326.

48. Staub O, Gautschi I, Ishikawa T, Breitschopf K, Ciechanover A, Schild L, Rotin D: Regulation of stability and function of the epithelial $\mathrm{Na}+$ channel (ENaC) by ubiquitination. Embo J 1997, 16(21):6325-6336

49. Lu C, Pribanic S, Debonneville A, Jiang C, Rotin D: The PY motif of $\mathrm{ENaC}$, mutated in Liddle syndrome, regulates channel internalization, sorting and mobilization from subapical pool. Traffic 2007 in press.

50. Kamynina E, Tauxe C, Staub O: Distinct characteristics of two human Nedd4 proteins with respect to epithelial $\mathrm{Na}(+)$ channel regulation. Am \& Physiol Renal Physiol 200I, 28I(3):F469-477.

5I. Shimkets RA, Lifton RP, Canessa CM: The activity of the epithelia sodium channel is regulated by clathrin-mediated endocytosis. J Biol Chem 1997, 272(4I):25537-2554I.

52. Pradervand $S$, Wang $Q$, Burnier M, Beermann F, Horisberger JD, Hummler E, Rossier BC: A mouse model for Liddle's syndrome. J Am Soc Nephrol 1999, I O(I 2):2527-2533.

53. Palmer LG, Sackin H, Frindt G: Regulation of $\mathbf{N a}+$ channels by luminal $\mathrm{Na}+$ in rat cortical collecting tubule. J Physiol 1998, 509(Pt I): $15 \mid-162$

54. Kellenberger S, Gautschi I, Rossier BC, Schild L: Mutations causing Liddle syndrome reduce sodium-dependent downregulation of the epithelial sodium channel in the Xenopus oocyte expression system. J Clin Invest 1998, I 0 I( I 2):274 I-2750.

55. Chen SY, Bhargava A, Mastroberardino L, Meijer OC, Wang J, Buse P, Firestone GL, Verrey F, Pearce D: Epithelial sodium channel regulated by aldosterone-induced protein sgk. Proc Natl Acad Sci USA 1999, 96(5):25|4-2519.

56. Naray-Fejes-Toth A, Canessa C, Cleaveland ES, Aldrich G, Fejes-Toth $\mathrm{G}$ : sgk is an aldosterone-induced kinase in the renal collecting duct. Effects on epithelial na+ channels. J Biol Chem 1999 274(24): 16973-16978.

57. Debonneville C, Flores SY, Kamynina E, Plant PJ, Tauxe C, Thomas MA, Munster C, Chraibi A, Pratt JH, Horisberger JD, et al.: Phosphorylation of $\mathrm{Nedd4-2}$ by Sgk I regulates epithelial $\mathrm{Na(+)}$ channel cell surface expression. Embo J 200I, 20(24):7052-7059.

58. Snyder PM, Olson DR, Thomas BC: Serum and glucocorticoidregulated kinase modulates Nedd4-2-mediated inhibition of the epithelial Na+ channel. J Biol Chem 2002, 277(I):5-8.

59. Kjarland E, Keen TJ, Kleppe R: Does isoform diversity explain functional differences in the $14-3-3$ protein family? Curr Pharm Biotechnol 2006, 7(3):217-223.

60. Ichimura T, Yamamura H, Sasamoto K, Tominaga Y, Taoka M, Kakiuchi K, Shinkawa T, Takahashi N, Shimada S, Isobe T: 14-3-3 proteins modulate the expression of epithelial $\mathrm{Na}+$ channels by phosphorylation-dependent interaction with Nedd4-2 ubiquitin ligase. J Biol Chem 2005, 280( I 3): I3|87-13 | 94.

6I. Bhalla V, Daidie D, Li H, Pao AC, LaGrange LP, Wang J, Vandewalle A, Stockand JD, Staub O, Pearce D: Serum- and glucocorticoidregulated kinase I regulates ubiquitin ligase neural precursor cell-expressed, developmentally down-regulated protein 4-2 by inducing interaction with 14-3-3. Mol Endocrinol 2005, I 9( I 2):3073-3084.

62. Liang X, Peters KW, Butterworth MB, Frizzell RA: 14-3-3 isoforms are induced by aldosterone and participate in its regulation of epithelial sodium channels. I Biol Chem 2006, 28 I (24): 16323-I6332

63. Flores SY, Loffing-Cueni D, Kamynina E, Daidie D, Gerbex C, Chabanel S, Dudler J, Loffing I, Staub O: Aldosterone-induced serum and glucocorticoid-induced kinase I expression is accompanied by Nedd4-2 phosphorylation and increased $\mathrm{Na}+$ transport in cortical collecting duct cells. J Am Soc Nephrol 2005, I 6(8):2279-2287.

64. Loffing-Cueni D, Flores SY, Sauter D, Daidie D, Siegrist N, Meneton $\mathrm{P}$, Staub $\mathrm{O}$, Loffing J: Dietary sodium intake regulates the ubiquitin-protein ligase nedd4-2 in the renal collecting system. Am Soc Nephrol 2006, I 7(5): 1264-1274. 
65. Alvarez de la Rosa D, Zhang P, Naray-Fejes-Toth A, Fejes-Toth G, Canessa $\mathrm{CM}$ : The serum and glucocorticoid kinase sgk increases the abundance of epithelial sodium channels in the plasma membrane of Xenopus oocytes. J Biol Chem 1999, 274(53):37834-37839.

66. Shigaev A, Asher C, Latter H, Garty H, Reuveny E: Regulation of sgk by aldosterone and its effects on the epithelial $\mathbf{N a ( + )}$ channel. Am J Physiol Renal Physiol 2000, 278(4):F6|3-619.

67. Auberson M, Hoffmann-Pochon N, Vandewalle A, Kellenberger S, Schild L: Epithelial Na+ channel mutants causing Liddle's syndrome retain ability to respond to aldosterone and vasopressin. Am J Physiol Renal Physiol 2003, 285(3):F459-47I.

68. Diakov A, Korbmacher C: A novel pathway of epithelial sodium channel activation involves a serum- and glucocorticoidinducible kinase consensus motif in the $\mathbf{C}$ terminus of the channel's alpha-subunit. J Biol Chem 2004, 279(37):38I34-38I42.

69. Dahlmann A, Pradervand S, Hummler E, Rossier BC, Frindt G, Palmer LG: Mineralocorticoid regulation of epithelial $\mathrm{Na}+$ channels is maintained in a mouse model of Liddle's syndrome. Am J Physiol Renal Physiol 2003, 285(2):F310-318.

70. Morris RG, Schafer JA: cAMP Increases Density of ENaC Subunits in the Apical Membrane of MDCK Cells in Direct Proportion to Amiloride-sensitive $\mathbf{N a ( + )}$ Transport. J Gen Physiol 2002, I 20(I):7I-85.

7I. Butterworth MB, Edinger RS, Johnson JP, Frizzell RA: Acute ENaC stimulation by CAMP in a kidney cell line is mediated by exocytic insertion from a recycling channel pool. J Gen Physiol 2005, I 25(I):8I-10I.

72. Snyder PM: Liddle's syndrome mutations disrupt CAMP-mediated translocation of the epithelial $\mathrm{Na}(+)$ channel to the cell surface. J Clin Invest 2000, 105(I):45-53.

73. Snyder PM, Olson DR, Kabra R, Zhou R, Steines JC: CAMP and serum and glucocorticoid-inducible kinase (SGK) regulate the epithelial $\mathrm{Na}(+)$ channel through convergent phosphorylation of Nedd4-2. J Biol Chem 2004, 279(44):45753-45758.

74. Vallet V, Chraibi A, Gaeggeler HP, Horisberger JD, Rossier BC: An epithelial serine protease activates the amiloride-sensitive sodium channel. Nature 1997, 389(665 I):607-610.

75. Hughey RP, Bruns JB, Kinlough CL, Harkleroad KL, Tong Q, Carattino MD, Johnson JP, Stockand JD, Kleyman TR: Epithelial sodium channels are activated by furin-dependent proteolysis. J Biol Chem 2004, 279(18): |8|||-|8||4.

76. Hughey RP, Bruns JB, Kinlough CL, Kleyman TR: Distinct pools of epithelial sodium channels are expressed at the plasma membrane. J Biol Chem 2004, 279(47):4849 I-48494.

77. Hughey RP, Mueller GM, Bruns JB, Kinlough CL, Poland PA, Harkleroad KL, Carattino MD, Kleyman TR: Maturation of the epithelial $\mathrm{Na}+$ channel involves proteolytic processing of the alphaand gamma-subunits. J Biol Chem 2003, 278(39):37073-37082.

78. Knight KK, Olson DR, Zhou R, Snyder PM: Liddle's syndrome mutations increase $\mathrm{Na}+$ transport through dual effects on epithelial $\mathrm{Na}+$ channel surface expression and proteolytic cleavage. Proc Natl Acad Sci USA 2006, 103(8):2805-2808.

\section{Publication history}

Republished from Current BioData's Targeted Proteins database (TPdb; http://www.targetedproteinsdb.com).

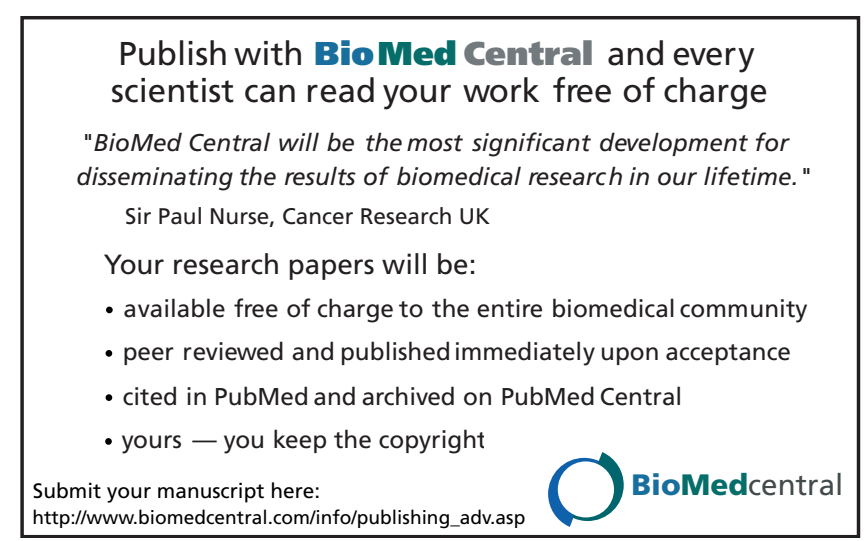

